\section{Peroxin Puzzles and Folded Freight: Peroxisomal Protein Import in Review}

\author{
Wendy J. Crookes, Laura J. Olsen \\ Department of Biology, University of \\ Michigan, Ann Arbor, MI 48109-1048, USA
}

Peroxisomes are organelles that perform a variety of functions, including the metabolism of hydrogen peroxide and the oxidation of fatty acids. Peroxisomes do not possess organellar DNA; all peroxisomal matrix proteins are posttranslationally translocated into the organelle. The mechanism of peroxisomal protein translocation has been the subject of vigorous research in the past decade. Many of the proteins (peroxins, abbreviated Pex) that play critical roles in peroxisome biogenesis have been identified through functional complementation of yeast strains and of Chinese hamster ovary cell lines that are defective in peroxisome biogenesis. Researchers are now turning towards biochemical and genetic analyses of these peroxins to define their roles in peroxisome biogenesis and to discover interacting protein partners. Evidence suggests that some of the interacting partners include molecular chaperones. Several current models for peroxisomal protein import are presented.

Correspondence to: L.J. Olsen

\section{Introduction}

Peroxisomes are ubiquitous organelles that participate in hydrogen peroxide metabolism, $\beta$-oxidation of fatty acids, and other important metabolic pathways (Olsen and Harada 1995; van den Bosch et al. 1992). Peroxisomes usually measure $0.5-1.0 \mu \mathrm{m}$ in diameter and have a simple architecture; a single membrane encloses an electron-dense matrix that often appears granular or contains a crystalline core. Peroxisomes do not possess an organellar genome (Douglass et al. 1973; Kamiryo et al. 1982). All peroxisomal matrix proteins are encoded by nuclear genes, translated on free cytosolic ribosomes, and posttranslationally transported into the organelle (reviewed in Lazarow 1995; Olsen 1998; Rachubinski and Subramani 1995; Subramani 1993).

The fact that peroxisomal matrix proteins are synthesized in the cytoplasm implies the need for peroxisome-specific mechanisms to target and translocate these proteins across the peroxisomal membrane. Several predictions about how this system functions may be made from research in other posttranslational protein import systems, especially mitochondrial and chloroplastic protein import (Haucke and Schatz 1997; Rassow and Pfanner 1995; Schatz and Dobberstein 1996). The first prediction is that peroxisomal proteins possess specific targeting signals. Second, these targeting signals interact with peroxisomal import receptors. Third, if protein conformation is essential for the protein's import competence, chaperone proteins may also interact with the targeted protein. Fourth, the targeted protein or its receptor interacts with components of the translocation apparatus. Fifth, the protein is translocated across the membrane through this apparatus.

These predictions seem straightforward; the overall model appears simple. Research in the past decade, 
however, has led to several unexpectedly complicated models for peroxisome biogenesis. This review focuses on three areas of peroxisome biogenesis research: peroxisomal targeting signals (PTSs); proteins which participate in peroxisome biogenesis, including chaperones; and the import competence of various assembly states of the targeted peroxisomal protein.

\section{Peroxisomal targeting signals}

Peroxisomal proteins are directed to the organelles by PTSs. Two types of signals have been identified for proteins destined for the peroxisomal matrix. The first, designated PTS1, is a carboxyl-terminal tripeptide that is necessary and sufficient to target proteins to peroxisomes (reviewed in Erdmann et al. 1997; Olsen 1998; Subramani 1993; Subramani 1996). A PTS1 consists of the amino acids serinelysine-leucine, or conserved substitutions of these residues. The position of the signal at the extreme carboxyl terminus of the protein is important for proper targeting; addition of amino acids to the carboxyl terminus beyond the tripeptide abolishes targeting of proteins to peroxisomes (Gould et al. 1989; Miyazawa et al. 1989). In addition, placement of a PTS1 at the amino terminus or at internal positions in a passenger protein does not target the passenger protein to peroxisomes (Subramani 1993). The majority of peroxisomal matrix proteins identified possess a PTS1 (de Hoop and AB 1992; Erdmann et al. 1997; Olsen and Harada 1991).

The second type of peroxisomal targeting signal (PTS2) contains a nine amino acid consensus sequence; the PTS2 nonapeptide is usually found within 20-30 amino acids of the amino terminus (reviewed in de Hoop and AB 1992; Erdmann et al. 1997; Gietl 1996; McNew and Goodman 1996; Olsen 1998; Roggenkamp 1992; Subramani 1993). In plants and mammals PTS2 sequences are cleaved in the organelle matrix, but cleavage is not required for import. In some yeasts, such as Saccharomyces cerevisiae, the signal remains uncleaved after import. Compared to the number of peroxisomal proteins that have PTS1 signals, few PTS2 proteins have been characterized. The most well-characterized PTS2 protein is thiolase, a fatty-acid $\beta$-oxidation enzyme found in plant, animal and yeast peroxisomes. Currently, three PTS2 proteins have been identified in mammals: thiolase (Bout et al. 1988; Hijikata et al. 1990; Osumi et al. 1991; Swinkels et al. 1991; Tsukamoto et al. 1994a), alkyl-dihydroxyacetonephosphate synthase (de Vet et al. 1998), and phytanoyl-
CoA hydroxylase (Jansen et al. 1997). Citrate synthase and malate dehydrogenase are PTS2 proteins in plants (Gietl 1990; Kato et al. 1996); amine oxidase and Pex8p are PTS2 proteins in yeasts (Bruinenberg et al. 1989; Faber et al. 1995; Waterham et al. 1994). Interestingly, Pex8p contains both PTS1 and PTS2 signal sequences (Waterham et al. 1994).

Compared to matrix protein targeting mechanisms, the targeting of peroxisomal membrane proteins is not well understood, primarily because few peroxisomal membrane proteins have been characterized. What is clear is that membrane proteins are targeted by a mechanism distinct from PTS1- and PTS2-protein targeting. Yeast strains defective in both PTS1and PTS2-protein import often possess an intact peroxisomal membrane, with membrane proteins, but they lack matrix proteins (Lazarow 1993; Purdue and Lazarow 1995; Subramani 1993; Subramani 1997; Van der Leij et al. 1992). The occurrence of these "peroxisomal membrane ghosts" indicates that peroxisomal membrane proteins are still targeted and inserted into the membrane and that they utilize a different pathway than the peroxisomal matrix proteins.

The targeting signals of four peroxisomal membrane proteins from yeasts have been studied. Candida boidinii Pmp47 is an integral membrane protein with six putative membrane-spanning domains (Dyer et al. 1996; McCammon et al. 1994). A 20 amino acid, matrixfacing, hydrophilic loop between the fourth and fifth transmembrane segments is both necessary and sufficient to target Pmp47 to the peroxisomal membrane. In contrast, Pichia pastoris Pex3p and Hansenula polymorpha Pex3p integral membrane proteins are targeted by 40 residues and 16 residues at the amino terminus, respectively (Baerends et al. 1996; Wiemer et al. 1996). Finally, the targeting signal for $S$. cerevisiae Pex15p is found within 82 amino acids of the carboxyl terminus, in the matrix-localized tail of the protein (Elgersma et al. 1997; Erdmann et al. 1997). This signal is necessary, but not sufficient for targeting Pex15p to peroxisomal membranes (Elgersma et al. 1997).

Interestingly, both $H$. polymorpha Pex $3 p$ and $S$. cerevisiae Pex15p can also be targeted to the endoplasmic reticulum (ER). Deletion of the Pex3p and Pex15p membrane targeting signals causes the proteins to accumulate in the ER (Elgersma et al. 1997). However, deletion of the Pmp47 targeting signal causes mislocalization to the cytosol (Dyer et al. 1996). Tabak and his colleagues (Elgersma et al. 1997) suggest that a subset of peroxisomal membrane proteins are targeted to peroxisomes through the ER (i.e., cotranslationally), while others rely on 
posttranslational transport from the cytosol. Thus, there may be two types of peroxisomal membrane targeting signals. The dual localization of Pex3p and Pex15p, and other evidence, has led some authors to propose that peroxisomes arise from ER-derived vesicles. Because the role of the ER in peroxisome biogenesis is beyond the scope of this review, interested readers should consult other discussions on this topic (e.g., Elgersma et al. 1997; Erdmann et al. 1997; Kunau and Erdmann 1998).

\section{Peroxins}

Significant progress in the field of peroxisomal protein import has come from the identification of the proteins responsible for peroxisome biogenesis; these proteins have been termed peroxins (pex). Peroxins are involved in matrix protein import, membrane biogenesis, peroxisome proliferation, and organelle inheritance. They are assigned numbers in accordance with a recently unified nomenclature system (Distel et al. 1996). Due in large part to the power of yeast genetics and to research on human peroxisome biogenesis disorders, over 20 peroxins have been identified and characterized (reviewed in Erdmann et al. 1997; McNew and Goodman 1996; Subramani 1996, 1997); these are summarized in Table 1 . Some of the peroxins share sequence homology with other, previously studied, protein families. Interactions between peroxins have been uncovered through two-hybrid screens and coimmunoprecipitation experiments. Despite these clues, little about the function of these proteins is understood.

Early screens for peroxisome biogenesis mutants in yeasts revealed that two classes of mutants were defective in the import of either PTS1 proteins or PTS2 proteins; most of the mutants were unable to import either type of protein (reviewed in Erdmann et al. 1997; McNew and Goodman 1996; Subramani 1996; Subramani 1997). This suggests models for peroxisome biogenesis in which there are two separate pathways for import, the PTS1 and the PTS2 pathways, that converge at some point and share some components in common.

pex 5 mutants are defective in the import of PTS1 proteins only (McCollum et al. 1993; Van der Leij et al. 1993). PEX5 encodes a protein that lacks predicted transmembrane domains and whose carboxyl terminus contains seven tetratricopeptide repeat (TPR) domains (Fransen et al. 1995; McCollum et al. 1993; Nuttley et al. 1995; Szilard et al. 1995; van der Klei et al. 1995; Van der Leij et al. 1993). Binding studies have shown that the TPR domain interacts with peptides containing PTS1-like peroxisomal targeting signals, but peptides lacking the PTS1 tripeptide do not bind (Brocard et al. 1994; McCollum et al. 1993; Terlecky et al. 1995). Thus, based on the specificity of Pex5p for the PTS1 targeting signal, Pex5p was designated the PTS1 receptor. Although Pex5p's ability to bind PTS1 sequences has been confirmed by several laboratories, there is no clear consensus on Pex5p's localization (see references in Table 1). Pex5p has been localized to the cytosol in $P$. pastoris and in $S$. cerevisiae, to the cytosol and peroxisomal matrix in $H$. polymorpha, and exclusively to the peroxisomal matrix in Yarrowia lipolytica. Pex5p appears to be cytosolic and peroxisomeassociated in humans.

Similarly, the isolation of a yeast strain defective specifically in the import of PTS2 proteins led to the identification of the PTS2 receptor, Pex7p (Braverman et al. 1997; Marzioch et al. 1994; Rehling et al. 1996; Zhang and Lazarow 1995; Zhang and Lazarow 1996). This protein is composed almost entirely of WD-40 ( $\beta$-transducin related) repeats. Pex7p binds specifically to PTS2 signals in vitro and interacts with thiolase in both two-hybrid and coimmunoprecipitation experiments. Interestingly, in S. cerevisiae Pex7p also interacts with Pex5p, suggesting an indirect role for Pex5p in PTS2 protein import. As with Pex $5 p$, the Pex $7 p$ sequence contains no recognizable transmembrane domains, and the protein has been localized to several subcellular locations (see refs. in Table I). Pex7p was found to be both cytosolic and intraperoxisomal in S. cerevisiae, but strictly cytosolic in Mus musculus.

Several models have been suggested to account for the various subcellular localizations of the PTS1 and PTS2 receptors (shown in Figs. 1-3; see Olsen 1998; Rachubinski and Subramani 1995; Waterham and Cregg 1997). In one model (Figs. 1, 3), cytosolic peroxisomal import receptors bind proteins destined for the peroxisomal matrix and accompany their cargo to the peroxisomal membrane. Included in this model are two hypotheses to explain the fate the receptor-peroxisomal protein complex at the membrane: (a) the receptor could deliver the cargo to the translocation apparatus, release the protein, and then recycle to the cytosol (shown for PTS1 proteins in Fig. 1A and for PTS2 proteins in Fig. 3); or (b) the receptor could be transported through the translocation machinery while still bound to the peroxisomal matrix protein (shown in Fig. 1B for a PTS1 protein). If receptors do enter the matrix of the organelle, they could be degraded or exported out of the organelle to the cytoplasm in a manner similar to nuclear import receptors. It should be noted that export of proteins out of peroxisomes has not been reported. (Further discussion of these models may 
Table 1. Peroxins ${ }^{a}$

\begin{tabular}{|c|c|c|c|}
\hline Name $^{b}$ & Proposed function/characteristics & Subcellular location & Ref. $^{c}$ \\
\hline Pex1p & $\begin{array}{l}\text { homologous to NSF proteins; contains two AAA-ATPase domains; } \\
\text { interacts with Pex6p; } 117-127 \mathrm{kDa}\end{array}$ & $\begin{array}{l}\text { cytoplasm; peripheral association with } \\
\text { non-peroxisomal vesicles }\end{array}$ & 1 \\
\hline $\operatorname{Pex} 2 p$ & contains $\mathrm{C}_{3} \mathrm{HC}_{4}$ zinc-finger motif; $35-52 \mathrm{kDa}$ & peroxisomal membrane (integral) & 2 \\
\hline Pex3p & $\begin{array}{l}\text { peroxisomal membrane synthesis; peroxisome proliferation; interacts with } \\
\text { Pex19p; mPTS in first } 40 \text { amino acids targets to both peroxisomes and } \\
\text { endoplasmic reticulum; } 51-52 \mathrm{kDa}\end{array}$ & peroxisomal membrane (integral) & 3 \\
\hline Pex4p & ubiquitin-conjugating protein; $21-24 \mathrm{kDa}$ & $\begin{array}{l}\text { peroxisomal membrane (peripheral, } \\
\text { cytosolic face) }\end{array}$ & 4 \\
\hline Pex5p & $\begin{array}{l}\text { PTS1 receptor; contains TPR motifs; interacts directly with Pex13p, } \\
\text { Pex14p, and Pex7p (probably), indirectly with Pex17p; 64-69 kDa }\end{array}$ & $\begin{array}{l}\text { cytoplasm; peroxisomal matrix; } \\
\text { peroxisomal membrane }\end{array}$ & 5 \\
\hline Pex6p & $\begin{array}{l}\text { homologous to NSF proteins; contains two AAA-ATPase domains; } \\
\text { some homology to myosin; interacts with Pex1p; 112-127 kDa }\end{array}$ & $\begin{array}{l}\text { cytoplasm; peripheral association with } \\
\text { non-peroxisomal vesicles }\end{array}$ & 6 \\
\hline $\operatorname{Pex} 7 \mathrm{p}$ & $\begin{array}{l}\text { PTS } 2 \text { receptor; interacts with Pex } 14 \mathrm{p} \text { and Pex } 5 \mathrm{p} \text { (probably); contains } \\
\text { WD- } 40 \text { motifs; } 37-42 \mathrm{kDa}\end{array}$ & $\begin{array}{l}\text { cytoplasm; peroxisomal matrix; } \\
\text { peroxisomal membrane }\end{array}$ & 7 \\
\hline Pex8p & contains both PTS1 and PTS2; 71-81 kDa & $\begin{array}{l}\text { peroxisomal matrix; peroxisomal } \\
\text { membrane (peripheral, matrix face) }\end{array}$ & 8 \\
\hline Pex9p & contains cysteine-rich region; $42 \mathrm{kDa}$ & peroxisomal membrane (integral) & 9 \\
\hline Pex10p & $\begin{array}{l}\text { peroxisome proliferation; lumen formation; contains } \mathrm{C}_{3} \mathrm{HC}_{4} \text { zinc-finger } \\
\text { motif; } 34-48 \mathrm{kDa}\end{array}$ & peroxisomal membrane (integral) & 10 \\
\hline Pex11p & peroxisome division; homodimerizes; $27-32 \mathrm{kDa}$ & $\begin{array}{l}\text { peroxisomal membrane (peripheral, } \\
\text { matrix face) }\end{array}$ & 11 \\
\hline $\operatorname{Pex} 12 \mathrm{p}$ & contains $\mathrm{C}_{3} \mathrm{HC}_{4}$ zinc-finger motif; $40-48 \mathrm{kDa}$ & peroxisomal membrane (integral) & 12 \\
\hline Pex13p & $\begin{array}{l}\text { putative docking protein for Pex5p; also interacts with Pex14p; contains } \\
\text { SH3 domain; } 40-43 \mathrm{kDa}\end{array}$ & peroxisomal membrane (integral) & 13 \\
\hline Pex14p & $\begin{array}{l}\text { interacts with both Pex } 5 p \text { and Pex } 7 p \text {; also interacts with itself, Pex } 13 p \text { and } \\
\text { Pex } 17 p \text {; putative point of convergence of PTS1 and PTS } 2 \text { pathways; } \\
38-39 \text { kDa }\end{array}$ & $\begin{array}{l}\text { peroxisomal membrane (integral, } \\
\text { peripheral, cytosolic face) }\end{array}$ & 14 \\
\hline Pex15p & $\begin{array}{l}\text { peroxisome proliferation; phosphorylated; O-glycosylated; mPTS in car- } \\
\text { boxyl-terminal (lumenal) tail is necessary, but not sufficient for targeting } \\
\text { to peroxisome; } 43.6 \mathrm{kDa}\end{array}$ & peroxisomal membrane (integral) & 15 \\
\hline Pex16p & peroxisome proliferation; $44.5 \mathrm{kDa}$ & $\begin{array}{l}\text { peroxisomal membrane (peripheral, } \\
\text { matrix face) }\end{array}$ & 16 \\
\hline Pex17p & interacts directly with Pex14p, indirectly with Pex5p; $23 \mathrm{kDa}$ & $\begin{array}{l}\text { peroxisomal membrane (peripheral, } \\
\text { cytosolic face) }\end{array}$ & 17 \\
\hline Pex19p & $\begin{array}{l}\text { farnesylated; interaction with Pex } 3 p \text { is dependent upon farnesylation; } \\
39.7 \mathrm{kDa}\end{array}$ & $\begin{array}{l}\text { cytoplasm; peroxisomal membrane } \\
\text { (peripheral, cytosolic face) }\end{array}$ & 18 \\
\hline $\operatorname{Pas} 22 \mathrm{p}$ & DnaJ homolog; 48 kDa & cytoplasm & 19 \\
\hline
\end{tabular}

a Adapted from similar tables in (Distel, Erdmann, 1996; Erdmann, Veenhuis, 1997; McNew and Goodman, 1996; Olsen, 1998; Subramani, 1997; Waterham and Cregg, 1997) and updated as necessary.

b Based on the unified nomenclature (Distel, Erdmann, 1996); proteins which are involved in peroxisome biogenesis are termed peroxins (acronym, PEX)

c References: 1. Erdmann et al. 1991; Faber et al. 1998; Heyman et al. 1994; Reuber et al. 1997; 2. Berteaux-Lecellier et al. 1995; Eitzen et al. 1996; Flaspohler et al. 1997; Shimozawa et al. 1992; Tsukamoto et al. 1991; Waterham et al. 1996; Tsukamoto et al. 1994b; 3. Baerends et al. 1996; Wiemer et al. 1996; 4. Crane et al. 1994; Wiebel and Kunau 1992; 5. Dodt et al. 1995; Fransen et al. 1995; Kalish et al. 1996; McCollum et al. 1993; Nuttley et al. 1995; Szilard et al. 1995; Terlecky et al. 1995; van der Klei et al. 1995; van der Leij et al. 1993; Wiemer et al. 1995; 6. Faber et al. 1998; Nuttley et al. 1994; Spong and Subramani 1993; Tsukamoto et al. 1995; Voorn-Brouwer et al. 1993; Yahraus et al. 1996; 7. Braverman et al. 1997; Marzioch et al. 1994; Motley et al. 1997; Rehling et al. 1996; Zhang and Lazarow 1995; Zhang and Lazarow 1996); 8. Liu et al. 1995; Smith et al. 1997; Waterham et al. 1994; 9. Eitzen et al. 1995; 10. Kalish et al. 1995; Tan et al. 1995; 11. Erdmann and Blobel 1995; Marshall et al. 1995; Sakai et al. 1995; 12. Chang et al. 1997; Kalish et al. 1996; 13. Elgersma et al. 1996; Erdmann and Blobel 1996; Gould et al. 1996; 14. Albertini et al. 1997; Brocard et al. 1997; Komori et al. 1997; 15. Elgersma et al. 1997; 16. Eitzen et al. 1997; 17. Huhse et al. 1998; 18. Götte et al. 1998; 19. Subramani 1997 
A.

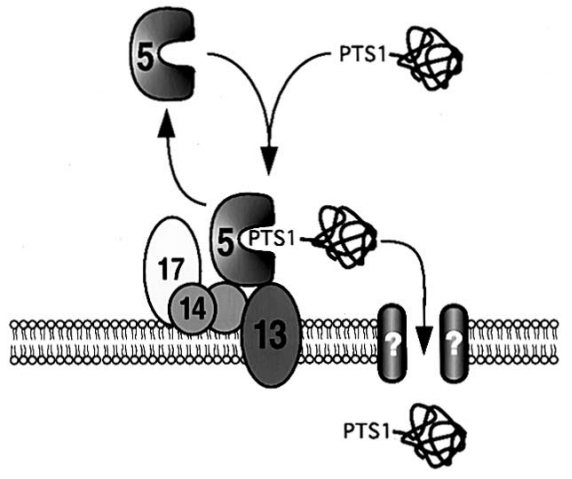

B.

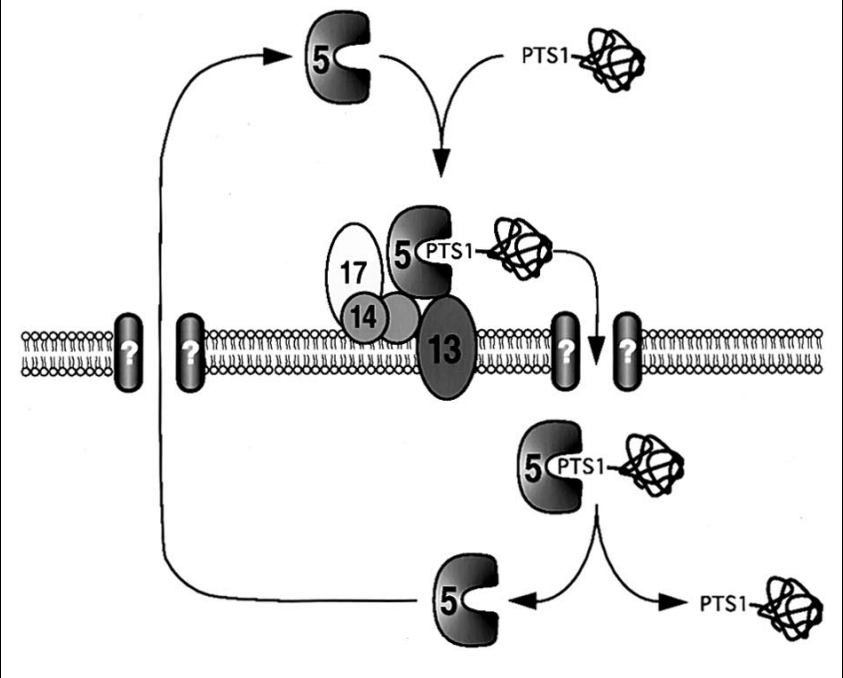

Fig. 1A,B. Models of PTS1 protein import with Pex5p shuttling between the cytosol and peroxisome. A) Cytosol to membrane shuttle. The PTS1 receptor, Pex5p, binds to the PTS1 protein in the cytoplasm. The Pex5p-PTS1 protein complex then docks on a membranebound peroxin complex that may include Pex13p, Pex14p and Pex17p. Pex5p dissociates from the PTS1 protein and is recycled back to the matrix as the PTS1 protein is translocated across the membrane. B) Cytosol to matrix shuttle. The Pex5p-PTS1 protein recognition and docking events occur as in A). In this model, however, the Pex5pPTS1 protein complex translocates across the membrane. Dissociation of the complex occurs in the matrix; Pex5p may be degraded or may recycle back to the cytoplasm. 5, Pex5p; 13, Pex13p; 14, Pex14p; 17, Pex17p

be found in Dodt and Gould 1996; Elgersma et al. 1996; Erdmann and Blobel 1996; Erdmann et al. 1997; Gould et al. 1996; Marzioch et al. 1994; Wiemer et al. 1995.)

In another model, the receptor is restricted to the organelle matrix or to the inner surface of the peroxisomal membrane (shown in Fig. 2 for a PTS1 protein) (see also Szilard et al. 1995; van der Klei et

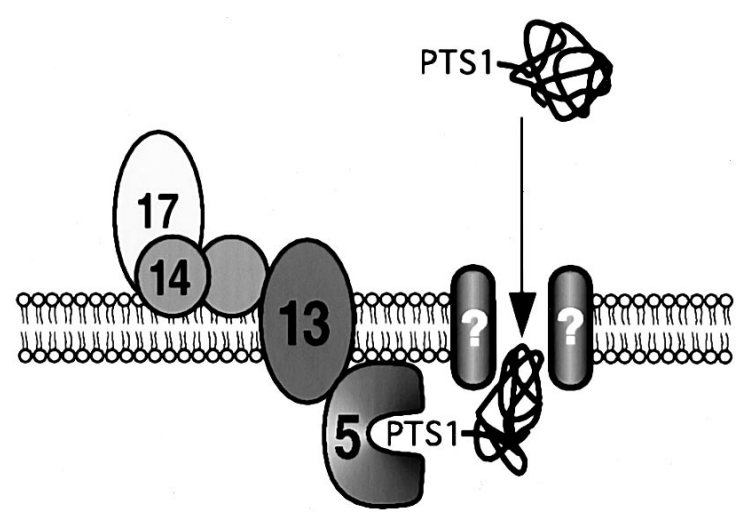

Fig. 2. Model of PTS1 protein import with Pex5p localized only inside the peroxisome. In this model the PTS1 receptor, Pex $5 p$, is peripherally bound to the matrix face of the peroxisomal membrane. The PTS1 protein translocates across the membrane and is bound by Pex5p as soon as it is exposed to the matrix. This binding prevents the PTS1 protein from slipping back through the translocation machinery, driving the transport event forward. 5, Pex5p; 13, Pex13p; 14, Pex14p; 17, Pex17p

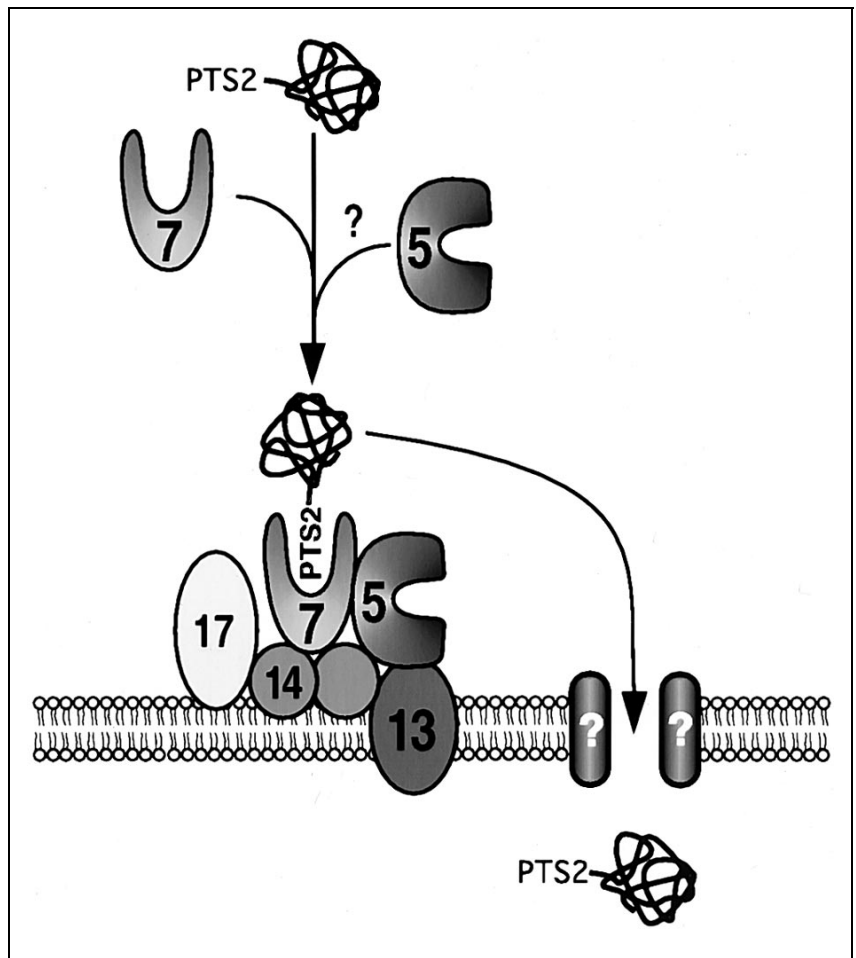

Fig. 3. One possible model for PTS2 protein import. The PTS2 receptor Pex7p binds to the PTS2 protein in the cytoplasm. In some species Pex $5 p$ may then join the complex by binding to Pex $7 p$. This complex then docks on the membrane bound peroxin complex, and the PTS2 protein is directed through the translocation machinery. This is comparable to the model shown in Fig. 1A for PTS1 proteins; other models, similar to those shown in Figs. 1B and 2 are also possible. A direct interaction between Pex5p and Pex7p may not always occur. 5, Pex5p; 7, Pex7p; 13, Pex13p; 14, Pex14p; 17, Pex17p 
al. 1995; Zhang and Lazarow 1996). The receptor is predicted to bind to the peroxisomal protein as soon as part of the targeted protein protrudes into the matrix. Binding would prevent the targeted protein from slipping back out of the apparatus and therefore would drive the translocation reaction forward. This "pulling" or "ratchet" mechanism is similar to the proposed function of mitochondrial hsp70s in facilitating mitochondrial protein import (Glick 1995; Martinus et al. 1995; Stuart et al. 1994).

Thus, based on findings with pex 5 and pex 7 mutants, it appears that there are two separate pathways for the initial steps of matrix peroxisomal protein import, one for each type of peroxisomal targeting signal. This raises the question of whether there are also PTS1- and PTS2-specific import channels or whether PTS1 and PTS2 proteins share components of a common import apparatus. Yeast peroxisome biogenesis mutants have again helped address this issue. Pex14p, which may function as a dimer, is a membrane protein that interacts with the PTS1 and PTS2 receptors (Albertini et al. 1997; Brocard et al. 1997; Komori et al. 1997). Based on these interactions and the inability of pex14 mutants to import both PTS1 and PTS2 proteins, Pex14p is thought to be a peroxisomal membrane docking protein for both receptors (see Figs. 1-3). Pex14p may therefore represent a point of convergence between the PTS1 and PTS2 import pathways.

Pex14p has also been shown to interact weakly with Pex13p, a peroxisomal integral membrane protein that contains an SH3 (Src homology 3) domain (Elgersma et al. 1996; Erdmann and Blobel 1996; Gould et al. 1996). As with pex14 mutants, pex13 mutants fail to import both PTS1 and PTS2 proteins into peroxisomes. Pex13p interacts with the PTS1 receptor but may not recognize the PTS2 receptor (compare Figs. 1A, 3; see Erdmann and Blobel 1996). Although the pex13 phenotype suggests that this strain is a general peroxisomal import mutant, it is not yet clear what role Pex13p plays in the PTS2 pathway.

Screens for yeast peroxisome biogenesis mutants have identified genes encoding several additional peroxisomal membrane proteins thought to be components of the translocation machinery (Figs. 1-3). Pex17p is a cytosol-facing, peripheral membrane protein that interacts directly with Pex14p and indirectly with Pex5p; the Pex17p-Pex5p interaction is mediated by the presence of Pex14p (Huhse et al. 1998). Pex $2 p$ and Pex12p are integral membrane proteins with zinc-finger motifs; pex 2 and pex12 mutant yeast strains accumulate the PTS1 receptor at the peroxisomal membrane (Chang et al. 1997; Eitzen et al. 1995; Kalish et al. 1996; Waterham et al.
1996). There are more than a dozen additional peroxins whose functions are poorly understood (see Table 1). Some of these peroxins may not be directly involved in import. Instead they may indirectly influence matrix protein import by perturbing peroxisome division or proliferation.

\section{Chaperones}

Protein import into organelles often requires cytosolic and/or organelle-specific chaperones. Chaperones, typicallyheat-shock proteins (Hsps), are involved in controlling protein folding in many cellular reactions (Hartl 1996; Miernyk 1997; Rassow et al. 1997). Chaperones such as Hsp70 (70-kDa class of heat-shock proteins) bind to proteins soon after synthesis in the cytoplasm. Chaperone binding prevents the nascent polypeptide from folding and thus maintains the protein in a loosely folded conformation. This extended conformation is often necessary to facilitate translocation across organellar membranes (Rassow and Pfanner 1995).

Hsp70 chaperones are probably involved in peroxisomal protein import. Antibodies against cytosolic Hsp70 have been shown to inhibit import of peroxisomal proteins. Microinjection of bovine Hsp73 antibodies into mammalian fibroblast cells inhibits peroxisomal protein import, but import is restored by the addition of exogenous Hsp70 (Walton et al. 1994). Results from our laboratory also indicate the importance of Hsp70s in peroxisomal protein import (Crookes and Olsen 1998). We have found that addition of antibodies directed against cytosolic wheat germ Hsp70 to in vitro import assays (Brickner et al. 1997; Brickner and Olsen 1998; Olsen 1998) lowers peroxisomal protein import levels. These antibodies also successfully immunoprecipitate two peroxisomal proteins, suggesting that Hsp70s and peroxisomal proteins interact directly.

Proteins related to Hsp70s have been localized to peroxisomes. PMP73, a 73-kDa peroxisomal integral membrane protein, is immunorelated to the Hsp70 family (Corpas and Trelease 1997). Another study has shown that proteins that crossreact with Hsp70 antibodies are recruited to the peroxisomal membrane during import; this Hsp70 has been localized to the outer leaflet of the peroxisomal membrane (Walton et al. 1994). Finally, a recently cloned watermelon Hsp70 is a putative peroxisomal matrix chaperone (Wimmer et al. 1997). The gene apparently possesses two in-frame translation initiation sites; synthesis from the second site would produce a protein containing a PTS2. 
Thus, Hsp70s may participate in peroxisomal protein import at several subcellular locations, and they may play multiple roles. Cytosolic Hsp70 might maintain the targeted matrix protein in an importcompetent state. In addition, cytosolic Hsp70 might stabilize the region of the protein containing the PTS until it is bound by the appropriate soluble PTS receptor (Subramani 1996). Intraperoxisomal Hsp70 might function as a "ratchetlike" protein, analogous to its putative role in mitochondrial protein import (Glick 1995; Martinus et al. 1995; Stuart et al. 1994), to assist in translocation of the protein across the membrane.

There is also evidence indicating the involvement of other chaperones, in addition to cytosolic Hsp70, in peroxisomal protein import. Since Hsp40s are chaperones that enhance Hsp70s' endogenous ATPase activity, it is not surprising that a prenylated, membrane-bound DnaJ (Hsp40) homolog has also been localized to the peroxisomal membrane (Preisig-Muller et al. 1994). No function has been attributed to this particular protein, however. Furthermore, Pas22p has been identified as a cytosolic DnaJ homolog (Subramani 1997).

In addition, it has been reported that a member of the Hsp60 family of chaperonins is located within the peroxisomal matrix (Velez-Granell et al. 1995). These proteins fold the transported polypeptide into its active conformation after translocation across mitochondrial and chloroplast membranes (Hartl 1996; Martinus et al. 1995; Stuart et al. 1994) and may play a similar role in peroxisomal protein assembly after transport.

Experiments from our laboratory have also shown that Hsp90 antibodies inhibit peroxisomal protein import in vitro (Crookes and Olsen 1998). Hsp90s function in a "super-chaperone" complex with Hsp70s to prime mammalian steroid receptors for ligand binding (Jakob and Buchner 1994; Pratt 1993; $\mathrm{Xu}$ and Lindquist 1993). Hsp90s also influence the assembly of protein complexes. Therefore the role of Hsp90 in peroxisomal protein import could be to prime the cytosolic PTS receptors for binding to recently synthesized peroxisomal proteins. It may also control the assembly state of the targeted protein or of the import complex prior to import.

\section{Protein folding and assembly}

The participation of molecular chaperones in peroxisomal protein import suggests that the folding state of the targeted peroxisomal protein could influence that protein's import competence. Several groups, however, have shown that oligomeric and fully folded substrates can be imported into peroxisomes (Hausler et al. 1996; Walton et al. 1995; Walton et al. 1994; Wendland and Subramani 1993). Examples of folded substrates that gain access to the peroxisomal matrix include albumin crosslinked to PTS1 peptides (Wendland and Subramani 1993) and dihydrofolate reductase-PTS1 fusion proteins stabilized in their folded state by aminopterin (Hausler et al. 1996). One of the most surprising results is that 9$\mathrm{nm}$ gold particles decorated with PTS1 signals enter the peroxisomal matrix (Walton et al. 1995).

Several laboratories have also used "piggy-backing" experiments to show that protein subunits are assembled in the cytosol prior to import (Glover et al. 1994; Lee et al. 1997; McNew and Goodman 1994). In these experiments an epitope-tagged peroxisomal protein construct lacking its PTS is coexpressed with the wild-type form of the peroxisomal protein (possessing a PTS). The epitope-tagged construct cannot reach the peroxisomal matrix without coexpression of the wild-type form, indicating that the two constructs probably associate prior to translocation. Although these studies cannot rule out that the assembled peroxisomal protein subunits dissociate at the membrane just before translocation, they demonstrate that an association between subunits must occur in the cytosol.

In contrast, it appears that some peroxisomal proteins are not assembled until after translocation across the peroxisomal membrane. For instance, assembly of octameric alcohol oxidase in $H$. polymorpha requires a peroxisomal factor (Evers et al. 1996). In addition, piggy-backing experiments similar to those described above have shown that P. pastoris alcohol oxidase cannot initiate oligomerization in the cytosol (Waterham et al. 1997). Therefore, import of alchohol oxidase into peroxisomes must precede oligomerization. Moreover, studies from our laboratory suggest that the question may not be whether proteins that are assembled in the cytosol can reach the matrix, but rather how efficiently the assembled proteins are translocated (Crookes and Olsen 1998). Whereas tetrameric isocitrate lyase can be imported into pumpkin peroxisomes in vitro, import of monomeric isocitrate lyase is much more efficient. Therefore, although folded and assembled substrates may be competent for import, loosely folded or monomeric substrates may be the preferred substrates for translocation.

Several models describing possible mechanisms for import of folded substrates have been proposed (see Erdmann et al. 1997; McNew and Goodman 1996; Subramani 1996; Waterham and Cregg 1997). In one model, peroxisomal proteins are imported predominantly as monomers, in a loosely folded conforma- 
tion. This mechanism is similar to that described for mitochondrial protein import (Hartl and Neupert 1990; Neupert et al. 1990). A second possibility is that oligomeric peroxisomal proteins are assembled in the cytosol and then disassembled or partially unfolded at the surface of the peroxisomal membrane. A chloroplast outer envelope membrane Hsp70 may provide chloroplast membranes with similar unfolding activity (Boston et al. 1996). This could also be the role for the putative membrane-bound Hsp70 and Hsp40 in peroxisomes. Another proposal is that assembled, oligomeric proteins are imported intact, i.e., without dissociation at the peroxisomal membrane. Finally, Goodman and colleagues have suggested that the peroxisomal membrane may invaginate into the matrix, enveloping assembled peroxisomal proteins, and then "bud off" into the peroxisomal matrix (McNew and Goodman 1994; McNew and Goodman 1996). The membrane vesicles would then degenerate and release their contents into the organellar matrix. Some support for this model is provided by a report in which internal membranes were observed in rat liver peroxisomes (Fahimi et al. 1993).

\section{Conclusions}

The peroxisome biogenesis models which have emerged over the past 10 years are far more complex than originally imagined: multiple targeting signals direct proteins to peroxisomes, at least two receptors interact with the targeted proteins, membrane components may bind to one receptor but not the other, additional membrane components may bind to both types of receptors, chaperones facilitate import, and folded substrates can be translocated. Over the past several years new peroxins have been rapidly identified. A few of these have been localized; several have been used in screens for interacting proteins. Studies on the localization and interactions of peroxins have given researchers a glimpse of how these proteins may function. There are, however, still many unanswered questions about the peroxisomal protein import pathway. Contributions from research programs utilizing yeast, mammalian, and plant systems will provide us with new information as we begin to unravel the surprisingly complex mechanisms of peroxisome biogenesis.

We thank Donna Brickner and Aaron Liepman for their helpful comments on this manuscript. All of the work performed in our laboratory was funded by the United States Department of Agriculture.
Albertini M, Rehling P, Erdmann R, Girzalsky W, Kiel JAKW, Veenhuis M, Kunau W-H (1997) Pex14p, a peroxisomal membrane protein binding both receptors of the two PTS-dependent import pathways. Cell 89:83-92

Baerends RJS, Rasmussen SW, Hilbrands RE, van der Heide M, Faber KN, Reuvekamp PTW, Kiel JAKW, Cregg JM, van der Klei IJ, Veenhuis M (1996) The Hansenula polymorpha PER9 gene encodes a peroxisomal membrane protein essential for peroxisome assembly and integrity. J Biol Chem 271:8887-8894

Berteaux-Lecellier V, Picard M, Thompson-Coffe C, Zickler D, Panvier-Adoutte A, Simonet JM (1995) A nonmammalian homolog of PAF1 gene (Zellweger syndrome) discovered as a gene involved in caryogamy in the fungus Podospora anserina. Cell 81:1043-1051

Boston RS, Viitanen PV, Vierling E (1996) Molecular chaperones and protein folding in plants. Plant Mol Biol 32:191-222

Bout A, Teunissen Y, Hashimoto T, Benne R, Tager JM (1988) Nucleotide sequence of human peroxisomal 3-oxoacyl-CoA thiolase. Nucleic Acids Res 16:10369

Braverman N, Steel G, Obie C, Moser A, Moser H, Gould S, Valle D (1997) Human PEX7 encodes the peroxisomal PTS2 receptor and is responsible for rhizomelic chondrodysplasia punctata. Nat Genet 15:369-376

Brickner DG, Harada JJ, Olsen LJ (1997) Protein transport into higher plant peroxisomes: in vitro assay provides evidence for receptor involvement. Plant Physiol 113:1213-1221

Brickner DG, Olsen LJ (1998) Nucleotide triphosphates are required for the transport of glycolate oxidase into peroxisomes. Plant Physiol 116:309-316

Brocard C, Kragler F, Simon MM, Schuster T, Hartig A (1994) The tetratricopeptide repeat-domain of the PAS10 protein of Saccharomyces cerevisiae is essential for binding the peroxisomal targeting signal -SKL. Biochem Biophys Res Commun 204:1016-1022

Brocard C, Lameschwandtner G, Koudelka R, Hartig A (1997) Pex $14 p$ is a member of the protein linkage map of Pex $5 p$. EMBO J 16:5491-5500

Bruinenberg PG, Evers M, Waterham HR, Kuipers J, Arnberg AC, AB G (1989) Cloning and sequencing of the peroxisomal amine oxidase gene from Hansenula polymorpha. Biochim Biophys Acta 1008:157-167

Chang CC, Lee WH, Moser H, Valle D, Gould SJ (1997) Isolation of the human PEX12 gene, mutated in group 3 of the peroxisome biogenesis disorders. Nat Genet 15:385-388

Corpas FJ, Trelease RN (1997) The plant 73kDa peroxisomal membrane protein (PMP73) is immunorelated to molecular chaperones. Eur J Cell Biol 73:49-57

Crane DI, Kalish JE, Gould SJ (1994) The Pichia pastoris PAS4 gene encodes a ubiquitin-conjugating enzyme required for peroxisome assembly. J Biol Chem 269:21835-21844

Crookes WJ, Olsen LJ (1998) The effects of chaperones and the influence of protein assembly on peroxisomal protein import. J Biol Chem 273:17236-17242

De Hoop MJ, AB G (1992) Import of proteins into peroxisomes and other microbodies. Biochem J 286:657-669

De Vet ECJM, IJlst L, Oostheim W, Wanders RJA, van den Bosch H (1998) Alkyl-dihydroxyacetonephosphate synthase. J Biol Chem 273:10296-10301

Distel B, Erdmann R, Gould SJ, Blobel G, Crane DI, Cregg JM, Dodt G, Fujiki Y, Goodman JM, Just WW, Kiel JAKW, Kunau W-H, Lazarow PB, Mannaerts GP, Moser HW, Osumi T, Rachubinski RA, Roscher A, Subramani S, Tabak HF, Tsukamoto T, Valle D, van der Klei I, van Veldhoven PP, Veenhuis M (1996) A unified nomenclature for peroxisome biogenesis factors. J Cell Biol $135: 1-3$

Dodt G, Gould SJ (1996) Multiple PEX genes are required for proper subcellular distribution and stability of Pex5p, the PTS1 receptor: evidence that PTS1 protein import is mediated by a cycling receptor. J Cell Biol 135:1763-1774 
Dodt G, Braverman N, Wong C, Moser A, Moser HW, Watkins P, Valle D, Gould SJ (1995) Mutations in the PTS1 receptor gene, PXR1, define complementation group 2 of the peroxisome biogenesis disorders. Nat Genet 9:115-125

Douglass SA, Criddle RS, Breidenbach RW (1973) Characterization of deoxyribonucleic acid species from castor bean endosperm. Inability to detect a unique deoxyribonucleic acid species associated with glyoxysomes. Plant Physiol 51:902-906

Dyer JM, McNew JA, Goodman JM (1996) The sorting sequence of the peroxisomal integral membrane protein PMP47 is contained within a short hydrophilic loop. J Cell Biol 133:296-280

Eitzen GA, Aitchison JD, Szilard RK, Veenhuis M, Nuttley WM, Rachubinski RA (1995) The Yarrowia lipolytica gene PAY2 encodes a 42-kDa peroxisomal integral membrane protein essential for matrix protein import and peroxisome enlargement but not for peroxisome membrane proliferation. J Biol Chem 270:1429-1436

Eitzen GA, Titorenko VI, Smith JJ, Veenhuis M, Szilard RK, Rachubinski RA (1996) The Yarrowia lipolytica gene PAY5 encodes a peroxisomal integral membrane protein homologous to the mammalian peroxisome assembly factor PAF-1. J Biol Chem $271: 20300-20306$

Eitzen GA, Szilard RK, Rachubinski RA (1997) Enlarged peroxisomes are present in oleic acid-grown Yarrowia lipolytica overexpressing the PEX16 gene encoding an intraperoxisomal peripheral membrane peroxin. J Cell Biol 137:1265-1278

Elgersma Y, Kwast L, Klein A, Voorn-Brouwer T, van den Berg M, Metzig B, America T, Tabak HF, Distel B (1996) The SH3 domain of the Saccharomyces cerevisiae peroxisomal membrane protein Pex13p functions as a docking site for Pex $5 p$, a mobile receptor for the import of PTS1-containing proteins. J Cell Biol 135:97-109

Elgersma Y, Kwast L, van den Berg M, Snyder WB, Distel B, Subramani S, Tabak HF (1997) Overexpression of Pex15p, a phosphorylated peroxisomal integral membrane protein required for peroxisome assembly in S. cerevisiae, causes proliferation of the endoplasmic reticulum membrane. EMBO J 16:7326-7341

Erdmann R, Blobel G (1995) Giant peroxisomes in oleic acid-induced Saccharomyces cerevisiae lacking the peroxisomal membrane protein Pmp27p. J Cell Biol 128:509-523

Erdmann R, Blobel G (1996) Identification of Pex13p, a peroxisomal membrane receptor for the PTS1 recognition factor. J Cell Biol 135:111-121

Erdmann R, Wiebel FF, Flessau A, Rytka J, Beyer A, Frohlich K-U, Kunau W-H (1991) PAS1, a yeast gene required for peroxisome biogenesis, encodes a member of a novel family of putative ATPases. Cell 64:499-510

Erdmann R, Veenhuis M, Kunau W-H (1997) Peroxisomes: organelles at the crossroads. Trends Cell Biol 7:400-407

Evers ME, Vladimir T, Harder W, van der Klei I, Veenhuis M (1996) Flavin adenine dinucleotide binding is the crucial step in alcohol oxidase assembly in the yeast Hansenula polymorpha. Yeast 12:917-923

Faber KN, Keiser-Gunnink I, Pluim D, Harder W, AB G, Veenhuis M (1995) The N-terminus of amine oxidase of Hansenula polymorpha contains a peroxisomal targeting signal. FEBS Lett 357:115-120

Faber KN, Heyman JA, Subramani S (1998) Two AAA family peroxins, PpPex1p and PpPex6p, interact with each other in an ATPdependant manner and are associated with different subcellular membranous structures distinct from peroxisomes. Mol Cell Biol 18:936-943

Fahimi HD, Baumgart E, Volkl A (1993) Ultrastructural aspects of the biogenesis of peroxisomes in rat liver. Biochimie 75:201-208

Flaspohler J, Rickoll W, Beverley S, Parsons M (1997) Functional identification of a Leishmania gene related to the peroxin 2 gene reveals common ancestry of glycosomes and peroxisomes. Mol Cell Biol 17:1093-1101
Fransen M, Brees C, Baumgart E, Vanhooren JCT, Baes M, Mannaerts GP, Van Veldhoven PP (1995) Identification and characterization of the putative human peroxisomal C-terminal targeting signal import receptor. J Biol Chem 270:7731-7736

Gietl C (1990) Glyoxysomal malate dehydrogenase from watermelon is synthesized with an amino-terminal transit peptide. Proc Natl Acad Sci USA 87:5773-5777

Gietl C (1996) Protein targeting and import into plant peroxisomes. Physiol Plantarum 97:599-608

Glick B (1995) Can Hsp70 proteins act as force-generating motors? Cell 80:11-14

Glover JR, Andrews DW, Rachubinski RA (1994) Saccharomyces cerevisiae peroxisomal thiolase is imported as a dimer. Proc Natl Acad Sci USA 91:10541-10545

Götte K, Girzalsky W, Linkert M, Baumgart E, Kammerer S, Kunau W-H, Erdmann R (1998) Pex19p, a farnesylated protein essential for peroxisome biogenesis. Mol Cell Biol 18:616-628

Gould SJ, Keller G-A, Hosken N, Wilkinson J, Subramani S (1989) A conserved tripeptide sorts proteins to peroxisomes. J Cell Biol 108:1657-1664

Gould SJ, Kalish JE, Morrell JC, Bjorkman J, Urquhart AJ, Crane DI (1996) Pex13p is an SH3 protein of the peroxisome membrane and a docking factor for the predominantly cytoplasmic PTS1 receptor. J Cell Biol 135:85-95

Hartl FU (1996) Molecular chaperones in cellular protein folding. Nature 381:571-580

Hartl F-U, Neupert W (1990) Protein sorting to mitochondria: evolutionary conservations of folding and assembly. Science 247:930-938

Haucke V, Schatz G (1997) Import of proteins into mitochondria and chloroplasts. Trends Cell Biol 7:103-106

Hausler T, Stierhof Y, Wirtz E, Clayton C (1996) Import of a DHFR hybrid protein into glycosomes in vivo is not inhibited by the folateanalogue aminopterin. J Cell Biol 132:311-324

Heyman JA, Monosov E, Subramani S (1994) Role of the PAS1 gene of Pichia pastoris in peroxisome biogenesis. J Cell Biol 127:1259-1273

Hijikata M, Wen J-K, Osumi T, Hashimoto T (1990) Rat peroxisomal 3-ketoacyl-CoA thiolase gene. Occurrence of two closely related but differentially regulated genes. J Biol Chem 265:4600-4606

Huhse B, Rehling P, Albertini M, Blank L, Meller K, Kunau W-H (1998) Pex17p of Saccharomyces cerevisiae is a novel peroxin and component of the peroxisomal protein translocation machinery. $\mathrm{J}$ Cell Biol 140:49-60

Jakob U, Buchner J (1994) Assisting spontaneity: the role of Hsp90 and small Hsps as molecular chaperones. Trends Biochem Sci 19:205-211

Jansen GA, Ofman R, Ferdinandusse S, Ijlst L, Muijsers AO, Skjeldal OH, Stokke O, Jakobs C, Besley GTN, Wraith JE, Wanders RJA (1997) Refsum disease is caused by mutations in the phytanoylCoA hydroxylase gene. Nat Genet 17:190-193

Kalish JE, Theda C, Morrell JC, Berg JM, Gould SJ (1995) Formation of the peroxisome lumen is abolished by loss of Pichia pastoris Pas7p, a zinc-binding integral membrane protein of the peroxisome. Mol Cell Biol 15:6406-6419

Kalish JE, Keller G-A, Morrell JC, Mihalik SJ, Smith B, Cregg JM, Gould SJ (1996) Characterization of a novel component of the peroxisomal protein import apparatus using fluorescent peroxisomal proteins. EMBO J 15:3275-3285

Kamiryo T, Abe M, Okazaki K, Kato S, Shimamoto N (1982) Absence of DNA in peroxisomes of Candida tropicalis. J Bact $152: 269-274$

Kato A, Hayashi M, Kondo M, Nishimura M (1996) Targeting and processing of chimeric protein with the N-terminal presequence of the precursor to glyoxysomal citrate synthase. Plant Cell 8:1601-1611 
Komori M, Rasmussen SW, Kiel JA, Baerends RJ, Cregg JM, van der Klei IJ, Veenhuis M (1997) The Hansenula polymorpha PEX14 gene encodes a novel peroxisomal membrane protein essential for peroxisome biogenesis. EMBO J 16:44-53

Kunau W-H, Erdmann R (1998) Peroxisome biogenesis; back to the endoplasmic reticulum? Curr Biol 8:299-302

Lazarow PB (1993) Genetic approaches to studying peroxisome biogenesis. Trends Cell Biol 3:89-93

Lazarow PB (1995) Peroxisome structure, function, and biogenesis human patients and yeast mutants show strikingly similar defects in peroxisome biogenesis. J Neuropath Exp Neurol 54:720-725

Lee MS, Mullen RT, Trelease RN (1997) Oilseed isocitrate lyases lacking their essential type 1 peroxisomal targeting signal are piggybacked to glyoxysomes. Plant Cell 9:185-197

Liu H, Tan X, Russell KA, Veenhuis M, Cregg JM (1995) PER3, a gene required for peroxisome biogenesis in Pichia pastoris encodes a peroxisomal membrane protein involved in protein import. J Biol Chem 270:10940-10951

Marshall PA, Krimkevich YI, Lark RH, Dyer JM, Veenhuis M, Goodman JM (1995) Pmp27 promotes peroxisomal proliferation. J Cell Biol 129:345-355

Martinus RD, Ryan MT, Naylor DJ, Herd SM, Hoogenraad NJ, Hoj PB (1995) Role of chaperones in the biogenesis and maintenance of the mitochondrion. FASEB J 9:371-378

Marzioch M, Erdmann R, Veenhuis M, Kunau W-H (1994) PAS7 encodes a novel yeast member of the WD-40 protein family essential for import of 3-oxoacyl-CoA thiolase, a PTS2-containing protein, into peroxisomes. EMBO J 13:4908-4918

McCammon MT, McNew JA, Willy PJ, Goodman JM (1994) An internal region of the peroxisomal membrane protein PMP47 is essential for sorting to peroxisomes. J Cell Biol 124:915-925

McCollum D, Monosov E, Subramani S (1993) The pas8 mutant of Pichia pastoris exhibits the peroxisomal protein import deficiencies of Zellweger syndrome cells - The PAS8 protein binds to the $\mathrm{COOH}$-terminal tripeptide peroxisomal targeting signal, and is a member of the TPR protein family. J Cell Biol 121:761-764

McNew JA, Goodman JM (1994) An oligomeric protein is imported into peroxisomes in vivo. J Cell Biol 127:1245-1257

McNew JA, Goodman JM (1996) The targeting and assembly of peroxisomal proteins: some old rules do not apply. Trends Biochem Sci $21: 54-58$

Miernyk JA (1997) The 70kDa stress-related proteins as molecular chaperones. Trends Plant Sci 2:180-187

Miyazawa S, Osumi T, Hashimoto T, Ohno K, Miura S, Fujiki Y (1989) Peroxisome targeting signal of rat liver acyl-CoA oxidase resides at the carboxy terminus. Mol Cell Biol 9:83-91

Motley AM, Hettema EH, Hogenhout EM, Brites P, ten Asbrock AL, Wijberg FA, Baas F, Heijmans HS, Tabak HF, Wanders RJ, Distel B (1997) Rhizomelic chondrodysplasia punctata is a peroxisomal targeting disease caused by a nonfunctional PT52 receptor. Nat Genet $15: 377-380$

Neupert W, Hartl F-U, Craig EA, Pfanner N (1990) How do polypeptides cross the mitochondrial membranes? Cell 63:447-450

Nuttley WM, Szilard RK, Smith JJ, Veenhuis M, Rachubinski RA (1995) The PAH2 gene is required for peroxisome assembly in the methylotrophic yeast Hansenula polymorpha and encodes a member of the tetratricopeptide repeat family of proteins. Gene 160:33-39

Olsen LJ (1998) The surprising complexity of peroxisome biogenesis. Plant Mol Biol 38:163-189

Olsen LJ, Harada JJ (1991) Biogenesis of peroxisomes in higher plants. In: Huang AHC, Taiz L (ed) Molecular approaches to compartmentation and metabolic regulation. American Society of Plant Physiologists, Rockville, pp 129-137

Olsen LJ, Harada JJ (1995) Peroxisomes and their assembly in higher plants. Annu Rev Plant Physiol 46:123-146
Osumi T, Tsukamoto T, Hata S, Yokota S, Miura S, Fujiki Y, Hijikata M, Miyazawa S, Hashimoto T (1991) Amino-terminal presequence of the precursor of rat peroxisomal 3-ketoacyl-CoA thiolase is a cleavable signal peptide for peroxisomal targeting. Biochem Biophys Res Commun 181:947-954

Pratt WB (1993) The role of heat shock proteins in regulating the function, folding, and trafficking of the glucocorticoid receptor. J Biol Chem 268:21455-21458

Preisig-Muller R, Muster G, Kindl H (1994) Heat shock enhances the amount of prenylated Dnaj protein at membranes of glyoxysomes. Eur J Biochem 219:57-63

Purdue PE, Lazarow PB (1995) Identification of peroxisomal membrane ghosts with an epitope-tagged integral membrane protein in yeast mutants lacking peroxisomes. Yeast 11:1045-1060

Rachubinski RA, Subramani S (1995) How proteins penetrate peroxisomes. Cell 83:525-528

Rassow J, Pfanner N (1995) Molecular chaperones and intracellular protein translocation. Rev Physiol Biochem Pharmacol 126:199-264

Rassow J, von Ahsen O, Bomer U, Pfanner N (1997) Molecular chaperones: towards a characterization of the heat-shock protein 70 family. Trends Cell Biol 7:129-133

Rehling P, Marzioch M, Niesen F, Wittke E, Veenhuis M, Kunau WH (1996) The import receptor for the peroxisomal targeting signal 2 (PTS2) in Saccharomyces cerevisiae is encoded by the PAS 7 gene. EMBO J 15:2901-2913

Reuber B, Germain-Lee E, Collins C, Morrell J, Ameritunga R, Moser H, Valle D, Gould S (1997) Mutations in PEX1 are the most common cause of peroxisome biogenesis disorders. Nat Genet 17:445-448

Roggenkamp R (1992) Targeting signals for protein import into peroxisomes. Cell Biochem Funct 10:193-199

Sakai Y, Marshall PA, Saiganji A, Takabe K, Saiki H, Kato N, Goodman JM (1995) The Candida boidinii peroxisomal membrane protein Pmp30 has a role in peroxisomal proliferation and is functionally homologous to Pmp27 from Saccharomyces cerevisiae. J Bacteriol 177:6773-6781

Schatz G, Dobberstein B (1996) Common principles of protein translocation across membranes. Science 271:1519-1525

Shimozawa N, Tsukamoto T, Suzuki Y, Orii T, Shirayoshi Y, Mori T, Fujiki Y (1992) A human gene responsible for Zellweger syndrome that affects peroxisome assembly. Science 255:1132-1134

Smith JJ, Szilard RK, Marelli M, Rachubinski RA (1997) The peroxin Pex17p of the yeast Yarrowia lipolytica is associated peripherally with the peroxisomal membrane and is required for the import of a subset of matrix proteins. Mol Cell Biol 17:2511-2520

Spong AP, Subramani S (1993) Cloning and characterization of PAS5:a gene required for peroxisome biogenesis in the methylotrophic yeast Pichia pastoris. J Cell Biol 123:535-548

Stuart RA, Cyr DM, Craig EA, Neupert W (1994) Mitochondrial molecular chaperones: their role in protein translocation. Trends Biochem Sci 19:87-92

Subramani S (1993) Protein import into peroxisomes and biogenesis of the organelle. Annu Rev Cell Biol 9:445-478

Subramani S (1996) Convergence of model systems for peroxisome biogenesis. Curr Opin Cell Biol 8:513-518

Subramani S (1997) PEX genes on the rise. Nat Genet 15:331-333

Swinkels BW, Gould SJ, Bodnar AG, Rachubinski RA, Subramani S (1991) A novel, cleavable peroxisomal targeting signal at the amino-terminus of the rat 3-ketoacyl-CoA thiolase. EMBO J 10:3255-3262

Szilard RK, Titorenko VI, Veenhuis M, Rachubinski RA (1995) Pay32p of the yeast Yarrowia lipolytica is an intraperoxisomal component of the matrix protein translocation machinery. J Cell Biol 131:1453-1469 
Tan X, Waterham HR, Veenhuis M, Cregg JM (1995) The Hansenula polymorpha PER8 gene encodes a novel peroxisomal integral membrane protein involved in proliferation. $J$ Cell Biol 128:307-319

Terlecky SR, Nuttley WM, McCollum D, Sock E, Subramani S (1995) The Pichia pastoris peroxisomal protein PAS8p is the receptor for the C-terminal tripeptide peroxisomal targeting system. EMBO J $14: 3627-3634$

Tsukamoto T, Miura S, Fujiki Y (1991) Restoration by a 35K membrane protein of peroxisome assembly in a peroxisome-deficient mammalian cell mutant. Nature 350:77-81

Tsukamoto T, Hata S, Yokota S, Miura S, Fujiki Y, Kijikata M, Miyazawa S, Hashimoto T, Osumi T (1994a) Characterization of the signal peptide at the amino terminus of the rat peroxisomal 3-ketoacyl-CoA thiolase precursor. J Biol Chem 269:6001-6010

Tsukamoto T, Shimozawa N, Fujiki Y (1994b) Peroxisome assembly factor 1:a nonsense mutation in a peroxisome-deficient Chinese hamster cell mutant and deletion analysis. Mol Cell Biol $14: 5458-5465$

Tsukamoto T, Miura S, Nakai T, Yokota S, Shimozawa N, Suzuki Y, Orii T, Fujiki Y, Sakai F, Bogaki A, Yasumo H, Osumi T (1995) Peroxisome assembly factor-2, a putative ATPase cloned by functional complementation on a peroxisome-deficient mammalian cell mutant. Nat Genet 11:395-401

Van den Bosch H, Schutgens RBH, Wanders RJA, Tager JM (1992) Biochemistry of peroxisomes. Annu Rev Biochem 61:157-197

Van der Klei IJ, Hilbrands RE, Swaving GJ, Waterham HR, Vrieling EG, Titorenko VI, Cregg JM, Harder W, Veenhuis M (1995) The Hansenula polymorpha PER3 gene is essential for the import of PTS1 proteins into the peroxisomal matrix. J Biol Chem 270:17229-17236

Van der Leij I, Van den Berg M, Boot R, Franse M, Distel B, Tabak HF (1992) Isolation of peroxisome assembly mutants from Saccharomyces cerevisiae with different morphologies using a novel positive selection procedure. J Cell Biol 119:153-162

Van der Leij I, Franse MM, Elgersma Y, Distel B, Tabak HF (1993) PAS10 is a tetratricopeptide-repeat protein that is essential for the import of most matrix proteins into peroxisomes of Saccharomyces cerevisiae. Proc Natl Acad Sci USA 90:11782-11786

Velez-Granell CS, Arias AE, Torres-Ruiz JA, Bendayan M (1995) Presence of Chromatium vinosum chaperonins 10 and 60 in mitochondria and peroxisomes of rat hepatocytes. Biol Cell 85:67-75

Voorn-Brouwer T, van der Leij I, Hemrika W, Distel B, Tabak HF (1993) Sequence of the PAS8 gene, the product of which is essential for biogenesis of peroxisomes in Saccharomyces cerevisiae. Biochim Biophys Acta 1216:325-328

Walton PA, Wendland M, Subramani S, Rachubinski RA, Welch WJ (1994) Involvement of $70 \mathrm{kD}$ heat-shock proteins in peroxisomal import. J Cell Biol 125:1037-1046

Walton PA, Hill PE, Subramani S (1995) Import of stably folded proteins into peroxisomes. Mol Biol Cell 6:675-683
Waterham HR, Cregg JM (1997) Peroxisome biogenesis. Bioessays 19:57-66

Waterham HR, Titorenko VI, Haima P, Cregg JM, Harder W, Veenhuis M (1994) The Hansenula polymorpha PER1 gene is essential for peroxisome biogenesis and encodes a peroxisomal matrix protein with both carboxy- and amino-terminal targeting signals. J Cell Biol 127:737-749

Waterham HR, de Vries Y, Russell KA, Xie W, Veenhuis M, Cregg JM (1996) The Pichia pastoris PER6 gene product is a peroxisomal integral membrane protein essential for peroxisome biogenesis and has sequence similarity to the Zellweger Syndrome protein PAF-1. Mol Cell Biol 16:2527-2536

Waterham HR, Russell KA, de Vries Y, Cregg JM (1997) Peroxisomal targeting, import, and assembly of alcohol oxidase in Pichia pastoris. J Cell Biol 139:1419-1431

Wendland M, Subramani S (1993) Cytosol-dependent peroxisomal protein import in a permeabilized cell system. J Cell Biol 120:675-685

Wiebel FF, Kunau W-H (1992) The Pas2 protein essential for peroxisome biogenesis is related to ubiquitin-conjugating enzymes. Nature 359:73-76

Wiemer EAC, Nuttley WM, Bertolaet BL, Li X, Francke U, Wheelock MJ, Anne UK, Johnson KR, Subramani S (1995) Human peroxisomal targeting signal-1 receptor restores peroxisomal protein import in cells from patients with fatal peroxisomal disorders. J Cell Biol 130:51-65

Wiemer EAC, Luerst GH, Faber KN, Wenzel T, Veenhuis M, Subramani S (1996) Isolation and characterization of Pas $2 p$, a peroxisomal membrane protein essential for peroxisome biogenesis in the methylotrophic yeast Pichia pastoris. J Biol Chem 271:18973-18980

Wimmer B, Lottspeich F, van der Klei I, Veenhuis M, Gietl C (1997) The glyoxysomal and plastid molecular chaperones $(70-\mathrm{kDa}$ heat shock protein) of watermelon cotyledons are encoded by a single gene. Proc Natl Acad Sci USA 94:13624-13629

$\mathrm{Xu} \mathrm{Y,} \mathrm{Lindquist} \mathrm{S} \mathrm{(1993)} \mathrm{Heat} \mathrm{shock} \mathrm{protein} \mathrm{hsp90} \mathrm{governs} \mathrm{the} \mathrm{activ-}$ ity of pp60v-src kinase. Proc Natl Acad Sci USA 90:7074-7078

Yahraus T, Braverman N, Dodt G, Kalish JE, Morrell JC, Moser HW, Valle D, Gould SJ (1996) The peroxisome biogenesis disorder group 4 gene, PXAAA1, encodes a cytoplasmic ATPase required for the stability of the PTS1 receptor. EMBO J 15:2914-2923

Zhang JW, Lazarow PB (1995) PEB1(PAS7) in Saccharomyces cerevisiae encodes a hydrophilic intra-peroxisomal protein that is a member of the WD repeat family and is essential for the import of thiolase into peroxisomes. J Cell Biol 129:65-80

Zhang JW, Lazarow PB (1996) Peb1p (Pas7p) is an intraperoxisomal receptor for the $\mathrm{NH}_{2}$-terminal, type 2 , peroxisomal targeting sequence of thiolase: Peb1p itself is targeted to peroxisomes by an $\mathrm{NH}_{2}$-terminal peptide. J Cell Biol 132:325-334 